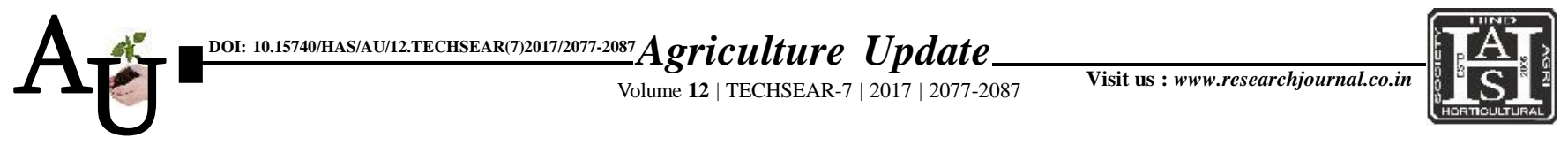

\title{
Research article: Studies on disease incidence and efficacy of fungicides, herbicides and antagonists micro flora against stem rot of rice (Sclerotium oryzae) along with integrated management
}

\author{
G. GOPIKA AND R. JAGADEESHWAR
}

Article Chronicle : Received :

19.07.2017;

Accepted :

03.08.2017

KEY WoRds:

Stem rot,

Antagonists,

Fungicides,

Herbicides, Rice,

Sclerotium oryzae

Author for correspondence :

\section{K. GOPIKA}

Department of Plant

Pathology, College of

Agriculture, Professor

JayashankarTelangana

State Agricultural

University,

Rajendranagar,

HYDERABAD (M.S.) INDIA

Email : gopikaagri@

gmail.com

See end of the article for

authors' affiliations
SUMMARY : Survey studies conducted in the rice growing districts of Telangana, revealed that incidence of stem rot disease varied from field to field ( 0 to $15 \%)$ in the surveyed districts of Khammam and Warangal. The disease incidence was varied from location to location. Highest disease incidence was recorded in late transplanted as compared to early transplanted crop. Maximum stem rot incidence (14.8\%) was recorded in rice-rice followed by rice-groundnut (3.8\%), rice-maize (2.8\%) and sunhemprice-maize-vegetables $(2.1 \%)$. Similarly, highest disease incidence was found in clay loam soils (14.0\%), followed by clay soils $(8.7 \%)$, loamy soils $(7.8 \%)$, while lowest incidence of stem rot was noted in fields with sandy soils (2.7\%) and sandy loam soils (2.6\%). The fields received with 151-180 $\mathrm{kg} \mathrm{N} \mathrm{ha}^{-1}$ showed highest disease incidence (11.1\%) followed by $120-150 \mathrm{~kg} \mathrm{~N} \mathrm{ha}^{-1}(8.1 \%)$ and $100-120 \mathrm{~kg} \mathrm{~N} \mathrm{ha}^{-1}(2.5 \%)$. Maximum disease incidence of stem rot was recorded in the fields which received pretilachlor (7.9\%) as compared to the fields received butachlor $(2.5 \%)$.studies conducted in the rice growing districts of Andhra Pradesh, revealed that incidence of stem. The mycoflora and bacteria were isolated from rhizosphere soil associated with diseased rice plants during the survey on Martin medium and soil extract agar medium, respectively. Mycoflora viz., Aspergillus flavus, A. niger, Cladosporium, Trichoderma viride isolate-1 and 2 while bacterial isolates viz., Pseudomonas fluorescens (BI-1), isolate-2 (BI-2), isolate-3 (BI-3), isolate-4 (BI-4), isolate-5 (BI-5) were found to be antagonistic to test pathogen $S$. oryzae. The detected mycoflora and bacterial isolates were further screened following dual culture technique and the results indicated that among mycoflora screened, T. viride (T1) was found to have most potential antagonistic effect with maximum inhibition $(75.3 \%)$ of test pathogen. Similarly among antagonistic bacterial isolates screened P. fluorescens (BI-1) was found to be highly effective in inhibiting the test pathogen by 77.2 per cent. These potential biocontrol agents can be exploited as an integrated approach in the management of stem rot of rice. The compatibility studies between $T$. viride $\left(\mathrm{T}_{1}\right)$ and $P$. fluorescens (BI-1) following dual culture technique under in vitro conditions indicated that the per cent inhibition of $T$. viride $\left(\mathrm{T}_{1}\right)$ by $P$. fluorescens was 5.0 per cent, while no inhibition was observed in the growth of $P$. fluorescens. Out of six fungicides tested, Hexaconazole @ 200 ppm and Propiconazole @ m100 ppm completely inhibited S. oryzae in poisoned medium. Out of two herbicides tested, the inhibition of test pathogen was high (97.1\%) in Butachlor (400 ppm) and least $(28.0 \%)$ in Oxadiargyl (150 ppm). In compatibility studies, $T$. viride $\left(\mathrm{T}_{1}\right)$ was incompatible with fungicides Propiconazole (100 ppm) and Hexaconazole ( $200 \mathrm{ppm})$. However, it was 60.6 per cent inhibited 